\title{
The Influence of Parents' Role and Parenting on Communication and Social Independence of Children in Kindergarten Cempaka Cluster, Central Banjarmasin Subdistrict
}

\author{
Novi Suma Setyawati*, Sulaiman, Noorhafizah \\ Master Program of Education Management, Universitas Lambung Mangkurat, Banjarmasin 70123, \\ Indonesia
}

\section{Article history:}

Submission July 2020

Revised September 2020

Accepted September 2020

${ }^{*}$ Corresponding author:

E-mail: nov.unyu85i@gmail.com

\begin{abstract}
Children's personality development is crucial for their future and parents have a great role in assuring it develops well. The purpose of the study is to determine the effect of parenting on communication and children's social independence in the Kindergarten Cluster Cempaka, Central Banjarmasin District. The study uses a quantitative approach with explanatory methods, including cause and effect. It had a population of 360, and a total of 189 people were selected using a proportional sample technique. The research instruments were questionnaires. To analyze the collected data the researcher used regression and path analysis. The results show that: first, parental role influences communication in the Cempaka Cluster Kindergarten with 0.620. Second, parenting influences parental communication by 0.391 . Third, the role of parents influences children's social independence by 0.568 . Fourth, parenting parents influence the social independence of children by 0.696 . Fifth, parental communication impacts children's social independence by 0.625 . Sixth, parents' role through communication has a significant impact on the independence of children, specifically 0.06566 . Lastly, there is an influence of parenting through communication on children's social independence of 0.1144 . Thus, parents need to understand how to educate children to make them Social Independence and promote self-understanding in daily life.
\end{abstract}

Keywords: Parents role, parenting against parental communication and social independence

\section{Introduction}

Independence of behavior is an aspect of human personality that cannot stand on its own. It is related to a confident individual who can adapt and manage everything by himself/herself (Parker, 2005). Independence can manifest in many ways, including what tasks or activities a person prefers, how meaningful the task is perceived to be, and how task success is evaluated and measured (Hoffman, 2015). The ability to be independent is not naturally gained. It is primarily based on the will and encouragement from others. Children not trained independently from an early age often depend on others, even in adulthood. The basic unit of children's education is families, where they learn about self-confidence before enrolling in informal learning institutions. Early education starts within the family before the child joins formal education. The development of the required children's character is indicated by the level of family influence (Maimunah, Aslamiah, \& Suriansyah, 2018).

Additionally, skills that provide opportunities to practice learning independence are critical. Students might have good learning independence in case they are motivated together by teachers and parents. The role of parents is very important in shaping the child's personality and enhance social abilities. Parents are very instrumental in training and educating children in their development. 
Parents should not be negligent in guiding, nurturing, and educating children because they need attention during growth and development (Rahmawati, Ahmad, \& Suriansyah, 2019). Many things can be done to ensure there are effective development and growth in childhood. Parents should always have the knowledge required to better educate their children. For instance, they need to teach children to be responsible for their decisions and freely understand their needs and interests.

Responsibility and role of parents are very important for children experiencing mental health disorders, especially retardation. They need to help them develop adaptive social behavior, such as the ability to be independent. For this reason, parents need to know the most effective ways of educating and shaping independence. Therefore, parental care and help is the most important social support system in childhood. Parental support is closely related to a child's academic success, self-concept, selfesteem, self-confidence, motivation, and mental health. It also involves school achievement, emotional, and adjustment in school and daily social environment.

Parenting in providing social independence help children better understand themselves. It is the best way parents can use to as an embodiment of a sense of responsibility to children. Moreover, the family plays a significant role in educating children religiously, socially, and individually.

Additionally, communication between parents and their young ones enhances social abilities. Communication is a process by which information is exchanged between individuals through a common system of symbols, signs, or behavior (Mish, 2009). It is the primary tool that people can use to express their ideas and values (Suleman \& Zairi, 2001), so not surprisingly, two-thirds of the waking hours are spent for communicating (Romas \& Sharma, 2017). It is a term that comes from the Latin word communis, which means "the same" refers to "same meaning" (Sugiharto \& Ramadhana, 2018).

How to communicate with each person might differ significantly, for instance, between children and parents, which is categorized based on interpersonal communication. Interpersonal communication is communication between people face-to-face, allowing each individual to directly catch other people's reactions, both verbally and non-verbally (Wardani, Suharsono, \& Amalia, 2019). However, like many other aspects of children's development, communication can be influenced as studied by Andika \& Sunarti (2018) in which family communication had a significant relationship with the speaking ability of early childhood in Rambai Village, Pariaman, Indonesia.

Parenting involves maintaining, caring, guiding, educating, training, and leading children (Purwanti, Suriansyah, Aslamiah, \& Dalle, 2019). The parents are the ones who shape the child's personality, offer the child role-models and benchmarks. The way the life partners communicate with each other, the same way will the child communicates with the parents; the way the parent relates to the child, the same the child will relate to the parent (Marilena, 2015).

Children and parents often have close relationships. However, the child's closeness to parents is realistically separated by distance. In everyday life, communication allows receiving and providing information or messages based on what is needed. Theoretically, a variety of communication actions are recognized based on the context, such as interpersonal, oneself, group, organizational, and mass communication. This study specifically focuses on interpersonal communication. Parents' effective communication can be considered friendly by children, encouraging openness and mutual interactions. Children are given the freedom to express opinions, ideas, desires, and feelings and respond to others' opinions. Parents with effective communication patterns control children and help them develop good relationships with friends, deal with stress, and be interested in new things. Besides that, effective parentchild communication helps the parent control, supervise, and support the child (Lestari, 2012). The problem witnessed at the moment is the inability of parents to shape the abilities of children. It is the responsibility of parents to instill abilities, such as self-confidence, in chil- 
dren. Generally, the family is the first environment for children to develop a sense of security, impacting mental development. However, there is sometimes a lack of openness between these two parties, and in most cases, parents can share the knowledge they have due to shame. The gap that often develops between daughters and parents that prevents them from asking about changes in their bodies.

Changes affect children's confidence, mainly due to the lack of information received. This problem can be avoided by enhancing communication between parents and children, especially young girls. There will be openness and trust, which are critical in dealing with problems. Parents are more open in giving direction and information and providing opportunities for them to talk about themselves. Parents also need to show empathy and attention while responding to the problems faced by children. With good communication, problems such as lack of confidence can be overcome. From observations and interviews, there is variation in the level of independence of children in Kindergarten Clusters. In the Central Cempaka Cluster Kindergarten, some children have not shown an independent attitude, with parents waiting for them in school. Some are always assisted in handling assignments given by teachers. Lack of confidence is also manifested in the failure to participate in the marching activities. This problem shows that children need to be trained in social independence.

This study examines The Influence of Parenting Patterns on Parental Communication and Social Independence of Children in Kindergarten Cempaka Kindergarten, Central Banjarmasin District." Specifically, it focuses on the influence of the following: (1) The role of parents in communication; (2) Parenting patterns on parental communication; (3) The role of parents on the social independence of children; (4) Parenting parents on the social independence of children; (5) Parental communication on children's social independence; (6) The role of parents through parental communication on the social independence of children; (7) Parenting patterns through parental communication on the social independence of children.

\section{Material and Methods}

This research uses a quantitative descriptive approach. It utilizes a descriptive method with associative techniques. Sugiyono (2014) defined correlation research as a study that aims to determine the relationship between two or more variables. This assertion is in line with Arikunto (2015), who stated that correlational research determines how strong the relationship is between variables. A high correlation means that two or more variables have a strong relationship with each other, while a weak correlation means that the variables are hardly related (Franzese \& Iuliano, 2019).

This study is intended to determine the relationship between the four variables, including the parent role $\left(\mathrm{X}_{1}\right)$, parenting (X2) as the independent variable and communication $(\mathrm{Z})$ as the correlator variable, and the child's social independence $(\mathrm{Y})$.

The population of the study consists of the parents of children in Cempaka Kindergarten. The accessible population included 360 parents. Importantly, this study used cluster sampling to determine each school sample, which consists of individual groups or clusters. A total of 189 parents of children attending these ten schools were used as samples. The research institution uses questionnaires on a Likert scale, while path analysis was used to analyze data.

\section{Results and Discussion \\ The influence of the role of parents on com- munication}

This section presents the regression test results from the effect of the role of parents on communication. The significant level was 0,000 $<0.05$ while regression or positive influence, was $Y=23,096+0.620 \mathrm{X} 1=23,716$. The positive value shows that the level of trust increases, and therefore, parents' role positively influences their communication, enabling them to educate children appropriately. The $r$ square analysis results show that $0.329=32.9 \%$ influenced the role of parents in communication. Ha is accepted, and therefore, the role of parents influence communication in the Kindergarten Cluster of Cempaka. 
The influence of the role of parents on communication

This section discusses the influence of parenting on communication at Kindergarten Cluster Cempaka. The significant level was 0,000 $<0.05$, while regression or positive influence was $\mathrm{Y}=35,033+0.6391 \mathrm{X} 1=35,424$. The results show that the level of trust increases, and therefore, parenting has a positive influence on parent communication with children. The $\mathrm{r}$ square analysis result was $0.163=16.3 \%$, which was on the influence of parenting on communication. Ho is rejected, and therefore, parenting affects communication in Kindergarten Cluster Cempaka. Before this, it was also proven that parenting patterns influenced the communication ability of a child. The permissive parenting pattern was proven as the main factor of the delayed communication ability of a child (Hasanah \& Sugito, 2020).

\section{The influence of the role of parents on the so- cial independence of children}

This section presents the results of the influence of the role of parents on the social independence of children in the Cempaka Cluster Kindergarten. The significant level was 0,000 $<0.05$, while regression or positive influence was $Y=67,688+0.586 \mathrm{X} 1=68,274$. The level of trust increases, and therefore, the better the role of parents in providing education to children, the better the child's social independence.The $r$ square analysis results show that $0.150=15 \%$, which examined the parental communication influence on independence. Ho is rejected, and therefore, the role of parents influences children's social independence.

The influence of parenting on the social independence of children
The result of the significant level was 0,000 $<0.05$, while regression or positive influence was $Y=63,982+0,696 X 1=64,678$. The positive value shows that the level of trust increases, and therefore, parenting has a positive influence on social independence. The results of the $r$ square analysis of parenting on independence showed were $0.265=26.5 \%$. The hypothesis test results show that Ho is rejected, meaning that parenting style influences children's independence. Previously, it was also proven that parenting had a significant relationship with a child's self-reliance, which was similar to the independence of children (Sunarti, 2016).

\section{The influence of parental communication on social independence}

The result of the significant level was 0,000 $<0.05$ while regression or positive influence was $Y=62,813+0.625 \mathrm{X} 1=63,438$. With the positive value, the presence of good parental communication positively influences children's social independence. The $r$ square analysis results on the influence of parental communication on children's independence were $0.200=$ $20 \%$. Therefore, communication has a positive influence on the independence of children.

The direct relationship of parents' role through communication to independence had a Standardized Coefficients beta of 0.196 with the contribution of parents through communication on the independence of children was 0.335 . Therefore, the level of indirect relationships is $0.196 \times 0.335=0.06566$. The result of each variable's sig level is $0,000<0.05$, meaning that Ho is rejected. Therefore, there is an indirect relationship between the roles of parents through communication on independence (Table 1).

Table 1. The influence of the role of parents through parental communication on the social independence of children

\begin{tabular}{llllllll}
\hline & B & Std. Error & Beta & & \\
\hline 1 & (Constant) & 56.880 & 5.367 & & 10.597 & .000 & \\
& Parents' role & .296 & .119 & .196 & 2.484 & .014 & \\
& Parents' Communication & .468 & .110 & .335 & 4.253 & .000 \\
\hline
\end{tabular}


The results of the termination coefficient are shown in Table 2 . The results of the significant level of the $\mathrm{F}$ test were $0,000<0.05$. The $\mathrm{r}$ square analysis shows that $0.226=22.6 \%$ of parents' role and communication influenced the children's social independence. Therefore, there are still other variables that have a $77.4 \%$ influence on social independence other than communication and parenting, as well as parents' role.

Table 2. The coefficient of determination on the influence of parents' role through communication on the independence of children

\begin{tabular}{lllll}
\hline Model & $\mathrm{R}$ & R Square & Adjusted R Square & $\begin{array}{l}\text { Std. The error of the Esti- } \\
\text { mate }\end{array}$ \\
\hline 1 & $.475^{\mathrm{a}}$ & .226 & .217 & 7.83591 \\
\hline
\end{tabular}

\section{The influence of parenting through communication against children's social independence}

The results are shown in Table 3:

Table 3. The results of the path analysis of the influence of parenting through communication on the independence of children

\begin{tabular}{|c|c|c|c|c|c|c|}
\hline & & \multicolumn{2}{|c|}{ Unstandardized Coefficients } & \multirow{2}{*}{$\begin{array}{l}\text { Standardized } \\
\text { cients } \\
\text { Beta }\end{array}$} & \multirow{2}{*}{$\underbrace{\text { Coeffi- }}_{t}$} & \multirow[b]{2}{*}{ Sig. } \\
\hline \multicolumn{2}{|c|}{ Model } & B & Std. Error & & & \\
\hline \multirow[t]{3}{*}{1} & (Constant) & 49.992 & 4.929 & & 10.142 & .000 \\
\hline & Parenting style & .540 & .088 & .400 & 6.106 & .000 \\
\hline & $\begin{array}{l}\text { Parents' communica- } \\
\text { tion }\end{array}$ & .399 & .091 & .286 & 4.368 & .000 \\
\hline
\end{tabular}

The influence of the parenting through communication on the independence of children

The result of the path analysis shows that the F-test significance level results were 0,000 $<0.05$. The level of contribution based on the path analysis of direct relationship parenting through communication on independence had Standardized Coefficients beta of 0,400. Par- enting through communication on independence was 0,286 . The level of indirect relationships was $0,400 \times 0,286=0,1144$. The result of the sig level of each variable is $0,000<0.05$, and therefore, Ho is rejected, meaning there is an indirect relationship between parenting through communication and the independence of children. The result of the termination coefficient is shown in Table 4.

Table 4. Determination coefficient results in the influence of parenting through communication on the independence of children

\begin{tabular}{lllll}
\hline Model & R & R Square & Adjusted R Square & $\begin{array}{l}\text { Std. The error of the Esti- } \\
\text { mate }\end{array}$ \\
\hline 1 & $.577^{a}$ & .333 & .326 & 7.26964
\end{tabular}

The results of the $r$ square analysis on the influence of parenting through communication on children's independence was $0.333=33.3 \%$ gave the influence of parenting through communication. Therefore, other variables influence childbirth. There were still other variables with influence from $100 \%$ to $11.4 \%$. The results of the path analysis can be described as follows: (1) Their role of parents influences communication by 0.620 ; (2) Parenting style affects the communication of parents by 0.391 ; (3) The role of parents impacts children's social 
independence by 0.568 ; (4) Parenting style influences the social independence of children by 0.696; (5) Parental communication impacts children's social independence by 0.625 ; (6) Their role of parents through communication influence the independence of children by 0.06566; (7) The parenting patterns through communication influence the social independence of children by 0.1144 .

The study results show that family communication, especially parents, has a significant impact on children's independence and social independence. Children's personalities and must be trained in children as early as possible optimally to avoid hindering their development (Damayanti, 2020). Children's independence behavior includes the ability to manage themselves and the ability to make a decision as well as solve a problem (Nurfalah, 2010). Children are categorized as independent in case they can decide to act, responsible, are not dependent on other people, believe in themselves (Yamin \& Sanan, 2013), self-directed, be able to develop themselves, and be adaptable to the environment (Widianti, Purwadi, \& Khasanah, 2019).

Parents and siblings' role is one of the major factors that influence children's independence (Susanto, 2017). Their roles are to provide basic education, attitude, and basic skills, such as religious education, morals, ethics, aesthetics, love, security, obey rules and nurturing good behaviors (Hasan, 2009). Family and environment support the development of independence in children and helps them take responsibility for their decisions (Novitawati \& Mutiarany, 2016).

In case children rely on the environment or their closest people, especially parents, it can be difficult for them to make decisions. They might hesitate and fear taking responsibility for decisions made. The availability of opportunities to develop helps one become independent (Noorhafizah \& Dahlina, 2016). Providing training through simple things appropriate to their abilities and stages of child development is essential. Independence given early is very useful and impact future adult life. The role of parents helps develop independence in children. Appropriate parenting help children understand their lives and the problems faced, es- pecially in developing social abilities. The children's social abilities can be seen through their ability to choose friends, independent learning in class without parents, and sharing food with their friends (Wiyani, 2014). A child with good social ability could communicate easier with others to socialize, cooperate, and interact effectively with the environment (Lestiawati, 2013). The warmth of a parent in the family affects the child's subsequent relationship in adulthood. Parents influence their children's social relationships not only through their direct interactions with their children but also function as managers of their children's social lives and serve as regulators of opportunities for social contact with extrafamilial social partners (Parke et al., 2008). The attention of parents to children from an early age is crucial to the development of the soul and character (Suriansyah \& Mahriati, 2016) since this age is an important period in the formation of a child's personality, determining its future development prospects (Vasilyeva \& Shcherbakov, 2016).

The communication between parents and children helps in dealing with problems. Communication in a family should be open both for the bad and good situation and ready to deal with problems patiently, honestly, and openly (Wahidah, 2011). Self-openness has an important role in building closeness and confidence in a family (Ardhaneswari, 2018). Generally, most problems that arise in children are attributed to a lack of communication by parents. Effective interpersonal communication is characterized by openness, empathy, supportive behavior, positive behavior, and equality among communication actors (Rakhmat, 1998), mostly observed in a democratic parenting family (Amir \& Trianasari, 2013). It could highly influence the individual personality (Streeck, 1994). The intensity of communication in the family eventually influences the family behavior, closeness among the family members, or on the contrary, brings problems (Djuwitaningsih, 2018). The more the parents communicate with the children, the more they will improve their communication abilities and relate better to the people around them (Runcan, Constantineanu, Ielics, \& Popa, 2012). 


\section{Conclusion and Recommendation}

Based on the results of the study, it can be concluded that there is an influence of:

1. The role of parents on parent communication.

2. Parenting patterns on parental communication.

3. The role of parents on children's social independence.

4. Parenting parents on the social independence of children.

5. Parental communication on children's social independence.

6. The role of parents through parental communication on the social independence of children.

7. Parenting patterns through parental communication on children's social independence.

Based on the results of the study, the following recommendations are offered:

1. Schools should pay more attention to children and enhance their social independence by providing flexibility to the teachers to accomplish their responsibilities.

2. Parents should pay more attention to observe children's social behavior at home and not to pressure them.

3. The input material in understanding the influence of parental roles and parenting through communication on social independence should be examined more deeply in future studies.

Since this study is limited to parents' role on the children's personality other studies that explore parents' role for other things that related to children's education need to be conducted. Those studies will help the education institution to give a better education.

\section{Acknowledgment}

The authors say thanks to Master Program of Education Management for facilitating and supporting this research.

\section{References}

Amir, A. S., \& Trianasari. (2013). Interpersonal communication patterns in parenting: The case of parents with different religion. Jurnal Komunikasi Kareba, 2(1), 12-29.
Andika, Y., \& Sunarti, V. (2018, December). Relations between family communication and early childhood speaking ability in Rambai Village. Spektrum, 1(4), 545-552. doi:10.5281/zenodo.1492970

Ardhaneswari, G. Y. (2018). Communication between parents and children (A descriptive qualitative study on openness of adolescent to a single mother related to sexual behavior in Karangtengah Village, Ngawi Regency). Surakarta: Faculty of Communication and Information, University of Muhammadiyah Surakarta.

Arikunto, S. (2015). The basis of educational evaluation. Jakarta: Bumi Aksara.

Damayanti, E. (2020). Improving children independence through Montessori teaching method. Jurnal Obsesi: Jurnal Pendidikan Anak Usia Dini, 4(1), 475-482. doi:https://doi.org/10.31004/obsesi.v4i1.333

Djuwitaningsih, E. W. (2018, July). Family communication pattern in women worker from Indonesia. Jurnal Penelitian Komunikasi dan Opini Publik, 22(1), 64-74.

Franzese, M., \& Iuliano, A. (2019). Correlation analysis. In S. Ranganathan, M. Gribskov, K. Nakai, \& C. Schönbach (Eds.), Reference Module in Life Sciences: Encyclopedia of Bioinformatics and Computational Biology (Vol. 1, pp. 706721). Elsevier. doi:https://doi.org/10.1016/B978-0-12809633-8.20358-0

Hasan, M. (2009). PAUD (Early childhood education). Yogyakarta: DIVA Press.

Hasanah, N., \& Sugito. (2020). Analysis of parenting pattern on delay communication ability of early childhood. Jurnal Obsesi: Jurnal Pendidikan Anak Usia Dini, 4(2), 913-922. doi:https://doi.org/10.31004/obsesi.v4i2.465

Hoffman, B. (2015). A rose by any other name: The influence of culture on motivated behavior. In B. Hoffman, Motivation for Learning and Performance (pp. 107-136). Academic Press. doi:https://doi.org/10.1016/B978-0-12-8007792.00005-1

Lestari, S. (2012). Family psychology values development and conflict resolution in family. Jakarta: Kencana.

Lestiawati, I. M. (2013, December). The effect of parenting on social abilities of 6-7 years children. Jurnal Ilmiah Visi P2TK Paudni, 8(2), 111-119.

Maimunah, Aslamiah, \& Suriansyah, A. (2018). The integration of sentra-based learning and family program involvement at early childhood in developing character building (Multi case at Paud Mawaddah and Paud Alam Berbasis Karakter Sayang Ibu Banjarmasin, Indonesia). European Journal of Education Studies, 5(7). doi:http://dx.doi.org/10.5281/zenodo.1494207

Marilena, T. (2015). The role of parents in integrating their own children in society. Procedia - Social and Behavioral 
Sciences, $\quad 180, \quad 1680-1685$ doi:10.1016/j.sbspro.2015.05.067

Mish, F. C. (2009). Merriam-Webster's collegiate dictionary. Springfield: MS: MerriamWebster, Inc.

Noorhafizah, \& Dahlina. (2016, July). Improving learning outcome of social science in material of technology development by using Script Cooperative Learning Model with Horay Course Review in Class IV SDN Tatah Jaruju, Tatah Makmur District, Banjar Regency. Jurnal Paradigma, 11(2).

Novitawati, \& Mutiarany. (2016, July). Developing fine motoric (attaching picture accurately) through demonstration method combined with project method by using mozaic technique of rice and grains as basic materials in Group B of Taruna Banjarmasin Kindergarten. Jurnal Paradigma, 11(2).

Nurfalah, Y. (2010). Practical guidance to train early childhood independence. Bandung: PNFI Jayagiri.

Parke, R. D., Leidy, M. S., Schofield, T. J., Miller, M. A., \& Morris, K. L. (2008). Socialization. In M. M. Haith, \& J. B. Benson (Eds.), Encyclopedia of Infant and Early Childhood Development (pp. 224-235). Academic Press. doi:https://doi.org/10.1016/B978-012370877-9.001523

Parker, D. K. (2005). Developing children autonomy and confidence. Jakarta: Prestasi Pustaka.

Purwanti, R., Suriansyah, A., Aslamiah, \& Dalle, J. (2019). Introducing language aspect (English) to early childhood through the combination of picture and picture model, talking stick model, flashcard media, and movement and song method in B1 Group at Matahariku Bilingual Kindergarten Landasan Ulin Tengah Banjarb. European Journal of Education Studies, 5(7), 26-34. doi:http://dx.doi.org/10.5281/zenodo.1494188

Rahmawati, E., Ahmad, K. I., \& Suriansyah, A. (2019). Relationship between emotional intelligence, spiritual intelligence and teacher performance through work motivation as intervening variable in Islamic Elementary School in Banjarmasin, Indonesia. European Journal of Education Studies,

$5(11)$.

doi:http://dx.doi.org/10.5281/zenodo.2583976

Rakhmat, J. (1998). Communication psychology. Bandung: Remaja Rosdakarya.

Romas, J. A., \& Sharma, M. (2017). Effective communication. In J. A. Romas, \& M. Sharma, Practical Stress Management: A Comprehensive Workbook (7 ed., pp. 69-89). Academic Press. doi:https://doi.org/10.1016/B978-0-12-8112953.00004-8

Runcan, P. L., Constantineanu, C., Ielics, B., \& Popa, D. (2012). The role of communication in the parent-child interaction
Procedia-Social and Behavioral Sciences, 46, 904-908. doi:10.1016/j.sbspro.2012.05.221

Streeck, J. (1994). Culture, meaning and interpersonal communication. In M. L. Knap, \& G. R. Miller, Handbook of Interpersonal Communication. California: Sage Publication.

Sugiharto, S. A., \& Ramadhana, M. R. (2018, December). The effect of influencer credibility on the attitude of a brand (A case study on students of Faculty of Communication and Business of Telkom University). Jurnal Ilmu Politik dan Komunikasi, 8(2), 1-7.

Sugiyono. (2014). Educational research method quantitative, qualitative and R\&D approach. Bandung: Alfabeta.

Suleman, T., \& Zairi, M. (2001). Gaining agility through supply chain management. In A. Gunasekaran, Agile Manufacturing: The 21st Century Competitive Strategy (pp. 785-807). Elsevier. doi:https://doi.org/10.1016/B978008043567-1/50039-5

Sunarti, K. (2016, December). Relationship of parenting pattern and child self-reliance. Journal of EST, 2(3), 152-160.

Suriansyah, A., \& Mahriati, S. (2016, July). Improving learning outcome of concept of characteristics of building space by Two Way Two Stray learning model and real mediaof Class V students of SDN Pengambangan 8 Banjarmasin City. Jurnal Paradigma, 11(2).

Susanto, A. (2017). Development of early childhood: Introduction in any aspects. Jakarta: Bumi Aksara.

Vasilyeva, E. N., \& Shcherbakov, A. V. (2016). Parental roles and types of parentings as determinants of apreschooler's emotional and personal well-being. Procedia - Social and Behavioral Sciences, 233, 144 - 149. doi:10.1016/j.sbspro.2016.10.172

Wahidah, N. (2011). Communication pattern in family. Musawa, 3(2), 163-178.

Wardani, R. N., Suharsono, Y., \& Amalia, S. (2019). Relation between interpersonal communication with marriage satisfaction of carrer husband and wife. Cognicia, 7(2), 241-257.

doi:https://doi.org/10.22219/COGNICIA.Vol7.No2.241257

Widianti, D., Purwadi, \& Khasanah, I. (2019, July). The values of children autonomy through scaffolding of 3-4 years children in Kindergarten. Paudia, 8(1), 128-136. doi:10.26877/paudia.v8i1.4040

Wiyani, N. (2014). Nurturing early childhood character. Yogyakarta: Ar-Ruzz Media.

Yamin, M., \& Sanan, S. J. (2013). Guidance to early childhood education. Jakarta: Gaung Persada Press Group. 